\title{
Problems in fuelling spark ignition engines with dimethyl ether
}

This paper discusses briefly the production technology of dimethyl ether, taking into account plant raw materials and the physical and chemical properties of DME as compared to diesel fuel. The benefits and disadvantages of DME as a fuel are presented and changes in the emission of harmful substances characterised as compared to the combustion of diesel fuel. Also, basic usage problems are addressed, e.g. the wear of engine's elements, cavity and leakages in the fuel system.

Key words: alternative fuels, fuel system

\section{Introduction}

Extensive development of vehicle transport over the past decades has resulted in bigger consumption of engine fuels and rapid degradation of the environment. The need to ensure fuel supply - matching the growing demand - on world markets, combined with depleting crude oil resources brought a greater interest in alternative fuels. The selection of alternative fuels is determined by four criteria:

- availability of raw material,

- degree to which the production technology is available,

- impact on the degradation of environment throughout the entire life cycle (WtW),

- feasibility in terms of powering modern-day engines.

One of the alternative fuels that according to the aforesaid criteria appears more advantageous than a number of biofuels is dimethyl ether (DME) [2, 5, 11]. Its production has been developed chiefly in Asian countries - a major worldwide producer of DME is China, where coal is the basic raw material. In Europe there are several pilot installations, among others in Sweden and Denmark. Raw materials used for DME production may include:

- coal,

- natural gas,

- solid biomass,

- liquid biomass,

- biogas,

- waste, e.g. waste plastics.

High diversity of the raw materials that may be used stems from the method of producing the said fuel. Raw materials containing in their structure carbon and hydrogen, regardless of the manner of their bonding in particles are transformed into syngas, i.e. a combination of $\mathrm{CO}$ and $\mathrm{H}_{2}$ in adequate proportions. In the next phase syngas is used for the synthesis of methanol, of which DME is ultimately produced. Below are presented chemical reactions occurring in respective phases of DME synthesis.

Hydrogen essential for adjusting the composition of syngas is usually the product of conversion of carbon oxide into vapour:

$$
\mathrm{CO}+\mathrm{H}_{2} \mathrm{O} \longrightarrow \mathrm{CO}_{2}+\mathrm{H}_{2} \quad \Delta \mathrm{H}=-40.9 \mathrm{~kJ} / \mathrm{mol}
$$

Pyrolysis Gasification

raw material $(\mathrm{C}, \mathrm{H}) \rightarrow$ pyrolytic gas $\longrightarrow \mathrm{CO}, \mathrm{H}_{2}$

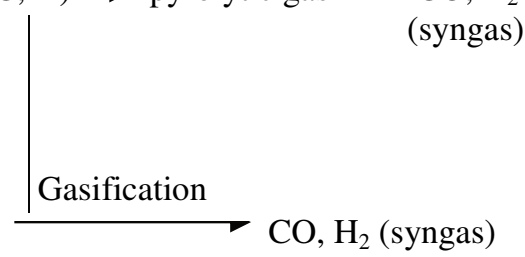

Syngas - a combination of $\mathrm{CO}$ and $\mathrm{H}_{2}$ in proportion suitable for the synthesis is the product of combining purified products of gasification with hydrogen:

$$
\begin{array}{cl}
\mathrm{CO}+2 \mathrm{H}_{2} \longrightarrow \mathrm{CH}_{3} \mathrm{OH} & \Delta \mathrm{H}=-90.7 \mathrm{~kJ} / \mathrm{mol} \\
\mathrm{CO}_{2}+3 \mathrm{H}_{2} \longrightarrow \mathrm{CH}_{3} \mathrm{OH}+\mathrm{H}_{2} \mathrm{O} \quad \Delta \mathrm{H}=-49.5 \mathrm{~kJ} / \mathrm{mol} \\
2 \mathrm{CH}_{3} \mathrm{OH} \longrightarrow \mathrm{H}_{3} \mathrm{COCH}_{3}+\mathrm{H}_{2} \mathrm{O}
\end{array}
$$

The aggregate process of DME synthesis from syngas is as follows:

$$
3 \mathrm{CO}+3 \mathrm{H}_{2} \longrightarrow \mathrm{CH}_{3} \mathrm{OCH}_{3}+\mathrm{CO}_{2} \quad \Delta \mathrm{H}=246.0 \mathrm{~kJ} / \mathrm{mol}
$$

The formula of DME synthesis reaction is unrelated to the raw material. In technological practice raw material has considerable impact on the chemical composition of gasification products, which must be purified from sulphur compounds (mainly $\mathrm{SO}_{3}$ ), partly $\mathrm{CO}_{2}$, non-combusted hydrocarbons and a number of other chemical pollutants. In case of certain raw materials this process is very problematic in terms of effective production of syngas of a particular purity and a specified $\mathrm{CO} / \mathrm{H}_{2}$ proportion.

Methane or bio-methane is another raw material attractive for DME/bioDME synthesis. If DME is synthetized from natural gas or biogas, the process chart is similar as the one presented above. The only difference takes place in the initial phase, where methane (biogas) is directly processed into syngas. Those technologies have been developed by BP Chemicals and Haldor Topsoe, and also several Japanese companies, in collaboration with Total oil and gas company. Another important aspect as regards the implementation and use of bioDME is the reduction of $\mathrm{CO}_{2}$ emissions in the fuel consumption chain. In accordance 
with Directive 2009/28/EC [6] bioDME is considered to reduce $\mathrm{CO}_{2}$ emission in the life cycle at the level of 92 $92 \%$, depending on the biomass material.

Due to its properties, DME may be stored and transported as LPG. Usually DME is stored in aboveground or underground containers with a horizontal axis and transported by road or railway tanks.

\section{DME physical and chemical parameters}

Dimethyl ether (DME), with a structure described by $\mathrm{CH}_{3}-\mathrm{O}-\mathrm{CH}_{3}$ formula in standard conditions $(0.1 \mathrm{MPa}$ pressure, temperature of $273.15 \mathrm{~K}$ ) is a colourless gas with a characteristic odour. Compressed under pressure higher than 0.6 MPa, it undergoes condensation. In such form it is considered as fuel for SI combustion engines [35]. Basic physical and chemical parameters of liquid DME compared to diesel fuel are presented in Table 1. There are references in literature to other values of parameters corresponding to DME properties.

Table 1. Chosen physical and chemical parameters of DME [10, 24, 27]

\begin{tabular}{|l|c|c|c|}
\hline Parameter & Unit & DME & ON \\
\hline Molar mass & $\mathrm{g} / \mathrm{mol}$ & 46.07 & $\mathrm{c} . \mathrm{a} .170$ \\
\hline Carbon content & $\% \mathrm{w} / \mathrm{w}$ & 13 & 14 \\
\hline Hydrogen content & $\% \mathrm{w} / \mathrm{w}$ & 13 & 14 \\
\hline Oxygen content & $\% \mathrm{w} / \mathrm{w}$ & 34.8 & 0 \\
\hline Hydrogen content & $\% \mathrm{w} / \mathrm{w}$ & 13 & 14 \\
\hline Oxygen content & $\% \mathrm{w} / \mathrm{w}$ & 34.8 & 0 \\
\hline Density & $\mathrm{kg} / \mathrm{m}^{3}$ & 667 & 831 \\
\hline Cetane number & & $>55$ & $40-50$ \\
\hline $\begin{array}{l}\text { Auto-ignition tempera- } \\
\text { ure }\end{array}$ & $\mathrm{K}$ & 508 & 523 \\
\hline Lower calorific value & $\mathrm{MJ} / \mathrm{kg}$ & 27.6 & 42.5 \\
\hline $\begin{array}{l}\text { Kinematic viscosity at } \\
40^{\circ} \mathrm{C}\end{array}$ & $\mathrm{mm}{ }^{2} / \mathrm{s}$ & $<0.1$ & 3 \\
\hline AFR & & 9.0 & 14.6 \\
\hline $\begin{array}{l}\text { Boiling point at } 1013,25 \\
\text { hPa }\end{array}$ & $\mathrm{K}$ & 248.1 & $450-643$ \\
\hline Vapour enthalpy & $\mathrm{kJ} / \mathrm{kg}$ & 467.13 & 300 \\
\hline $\begin{array}{l}\text { Surface tension at temp. } \\
298 \mathrm{~K}\end{array}$ & $\mathrm{~N} / \mathrm{m}$ & 0.012 & 0.027 \\
\hline Bulk modulus & $\mathrm{N} / \mathrm{m}^{2}$ & $6.37 \cdot 10^{8}$ & $14.86 \cdot 10^{8}$ \\
\hline $\begin{array}{l}\text { Vapour pressure at } \\
298 \mathrm{~K}\end{array}$ & $\mathrm{kPa}$ & 530 & $<10$ \\
\hline
\end{tabular}

\section{Benefits of DME as fuel for SI engines}

Low boiling temperature. The boiling temperature of DME is much lower than that of diesel fuel. Because of this parameter, liquid fuel injected to the engine's cylinder is promptly vaporised and therefore the self-ignition delay is shorter. With quick evaporation it is possible to use low injection pressure of (20-30) MPa [3], even in condition of the engine's high rotational speed.

Large cetane number. The cetane number indicating the combustion speed is higher for DME than for diesel fuel. Thus, compared to diesel fuel, DME has a much shorter self-ignition delay and in result the emission of nitrogen oxides [10] is reduced.

Mastered methods of storage and distribution. Because of similar physical and chemical properties of DME and the condensed mixture of propane and butane (LPG), the matter of their storage and distribution is considered well studied. DME can be stored in liquid form in condition of moderate pressure - above 0.6 MPa [10]. According to the results of studies conducted by High Pressure Gas Safe- ty of Japan [15], due to chemical stability during storage, the diffusion ratio and the risk of the tank's explosion in the course of heating are similar for DME and LPG.

Very low toxicity. DME is a volatile organic compound, with no carcinogenic or mutagen properties. Its toxicity is considered very low or insignificant [22]. Also, it is considered that DME does not have any hazardous impact on human health [18].

Non-corrosive for metals. DME does not have any corrosive effect on metals used in the construction of fuel systems in combustion engines [Błąd! Nie można odnaleźć źródła odwołania.0].

\section{Disadvantages of DME as fuel for SI engines}

Low calorific value. Because of the particle structure in DME which contains oxygen, its calorific value accounts for approx. $65 \%$ of the calorific value of diesel fuel [14]. Moreover, considering that the density of liquid DME comes to $80 \%$ of diesel fuel's density - to achieve a similar calorific effect, a twice greater quantity (in terms of volume) of DME must be injected to the engine's cylinder than that of diesel fuel [21].

Low viscosity. Compared to diesel fuel, DME characterises with very low (at least twenty times lower [31]) viscosity and in consequence also poorer lubricity. Those unfavourable properties cause leakages from the fuel system and also worsen the workability of its movable elements, thus making them more prone to wear due to greater friction [10].

Low bulk modulus. Liquid DME is two to four times more compressible than diesel fuel [30]. For this reason, in fuel systems in SI engines not adapted to the characteristics of liquid DME fuel pressure may be decreased in highpressure areas of injection systems.

Aggressive towards certain plastics. DME shows corrosive action in most elastomers, damaging sealing elements and other components of fuel systems made of elastomers $[7,10,34]$.

\section{Emission of harmful products of DME combustion}

DME produced on an industrial scale from methane can be also derived from renewable resources, e.g. wood. Combustion gases from DME-fuelled engines - compared to those powered with diesel fuel - contain less harmful substances, including particular matter, sulphur oxides and hydrocarbons. The emission of nitrogen oxides and carbon oxide may be smaller or greater, depending on the conditions of engine's operation [Błąd! Nie można odnaleźć źródła odwołania.0, 20]. Because of greater volatility of DME than that of diesel fuel, in case of leakage DME rapidly outflows to atmosphere, and thus does not contaminate soil.

Engines fuelled with DME [8, 13, 14] prove to emit less noise and less particular matter, THC and nitrogen oxides. Fuel consumption vs the generated energy is comparable with diesel oil. Studies on a one-cylinder AVL engine with engine displacement equal to $2000 \mathrm{~cm}^{3}$ with turbocharger and a charge-air cooler proved the following differences in emission compared to diesel fuel combustion - presented in Table 2 [24]. 
Table 2. Comparison of parameters of SI engine fuelled with diesel fuel and DME [24]

\begin{tabular}{|l|c|c|}
\hline & Diesel fuel & DME \\
\hline Max. power and torque & \multicolumn{2}{|c|}{ comparable } \\
\hline Fuel consumption & \multicolumn{2}{|c|}{ comparable } \\
\hline & 2.83 & 1.19 \\
\hline $\mathrm{NO}_{\mathrm{x}}(\mathrm{g} /[\mathrm{kW} \cdot \mathrm{h}])$ & 0.22 & 0.22 \\
\hline $\mathrm{THC}(\mathrm{g} /[\mathrm{kW} \cdot \mathrm{h}])$ & 0.06 & 0.015 \\
\hline $\mathrm{PM}(\mathrm{g} / /[\mathrm{kW} \cdot \mathrm{h}])$ & $5 \%$ & $0 \%$ \\
\hline Smoke levels & 88 & 78 \\
\hline Noise $\mathrm{dB}(\mathrm{A})$ & & \\
\hline
\end{tabular}

Due to high oxygen content and the lack of bonds between carbon atoms (C-C) in a DME particle, the use of that fuel in SI engines helps to reduce PM emission significantly compared to such emission in diesel-fuelled engines $[8,17]$. Particular matter present in exhaust gases from DME-fuelled engines is mainly the product of combustion of grease and additives in DME that improve its viscosity $[1,[23]]$. For this reason, the exhaust cleaning systems in SI engines fuelled with DME usually do not require any PM filtration systems.

The emission of nitrogen oxides resulting from the combustion of DME is not conclusive. It is assumed that because of a shorter self-ignition delay and also a smaller part of the fuel combusted before its full mixing, the emission of nitrogen oxides is lower [14]. The factors listed below reduce the maximum temperature in the combustion chamber and therefore reduce $\mathrm{NO}_{\mathrm{x}}$ emission. Nevertheless, increased $\mathrm{NO}_{x}$ emission as compared to a diesel-fuelled engine is possible. This is because of the extended period of the highest temperature throughout the combustion process [3].

The emission of hydrocarbons [4, 16, 19, 23, 26, 28] manifests in cases of a rich mixture, whether local or global. In case of DME, which contains oxygen particles in its structure, the occurrence of a rich mixture locally is limited owing to incomplete fuel \& air mixing. As regards carbon monoxide, an increase in the emission is recorded occasionally - compared to diesel fuel which may be attributed to longer injection while at the same time its pressure is lower and the diameter of openings in the fuel injection system is greater. However, reducing $\mathrm{HC}$ and $\mathrm{CO}$ emissions is relatively easy owing to popular oxidising catalytic reactors.

Because of a shorter self-ignition delay and the resulting slower increase of pressure inside the combustion chamber, a reduction of noise levels generated by the combustion engine is observed $[8,15]$.

There are several compounds that should be considered, even though they are not regulated, in fuelling SI engines with DME. The emission of formaldehydes [32, 33] is greater and also moderate emission of sulphur dioxide, polycyclic aromatic hydrocarbons, benzene, toluene and xylene $[32,33]$ may be expected.

Laboratory research has been conducted to evaluate the reactivity and ozone forming potential [12, 17, 24] when fuelling engines with DME. In a typical urban atmosphere the DME reactivity is equal to or lesser than in case of conventional fuel. Therefore, it is reasonable to assume that the use of DME - compared to conventional fuel - may have positive impact on ozone levels in urban agglomera- tions. DME resilience in troposphere has been estimated to last 5-6 days.

\section{Usage problems relating to SI engines fuelled with DME}

Pure DME cannot be considered as a substitute of diesel fuel. Its use for fuelling combustion engines requires a modification of the fuel system and the use of additives improving certain physical and chemical properties of DME.

Critical problems concerning the use of SI engines fuelled with DME are discussed below:

Excessive wear of elements of the fuel system due to greater friction. The relatively low viscosity of DME implies poor greasing properties of the fuel. This results in greater friction between the movable parts of certain elements of the fuel system such as injection pumps, pumps in Common Rail and injectors [Błąd! Nie można odnaleźć źródła odwołania.0], thus accelerating their wear.

Low viscosity of DME may be resolved by additives improving the lubricity, a change in materials used in the fuel systems and processing of surfaces exposed to greater wear because of friction [31]. Among those solutions the most effective may be considered additives enriching DME.

Positive results have been proved in using commercial additives for DME [9], mainly those improving its lubricating properties. Those additives can be added in an amount ranging from 100 to $1000 \mathrm{mg} / \mathrm{kg}$. Moreover, as fuel constituents improving its lubricity, added may be substances such as diesel, castor oil, vegetable oils and related esters [7, 15, 27, 29].

Fig. 1 presents examples of results of a lubricity study on DME, where DME is enriched with various additives, based on Medium Frequency Pressurised Reciprocating Rig [27], which is a modification of the standard HFRR method (High Frequency Reciprocating Rig), wherein the grease properties of fuel are expressed as the diameter of wear scad measured with precision up to $1 \mu \mathrm{m}$. DME additives included methyl esters of colza oil, castor oil and Lubrizol 539. For comparison, ill. 1 also shows additional lubricity criteria for diesel fuel.

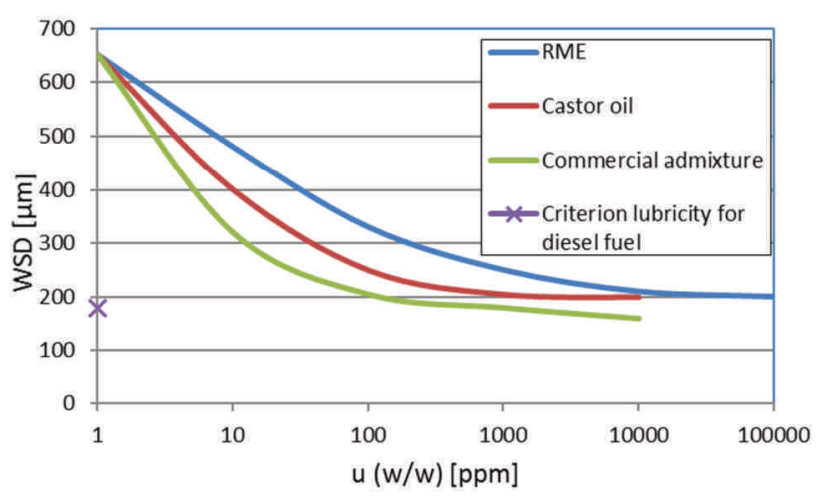

Fig. 1. Results of DME lubricity study - DME enriched with methyl esters of colza oil, castor oil and WSD (wear scad diameter) [27]

As illustrated by the above, even a small amount added of a substance improving lubricity changes DME properties considerably. According to the cited studies [2, 14], the 
commercial additive proved to be the most effective. A dose of $800 \mathrm{ppm}$ is sufficient to achieve lubricity comparable with that of diesel fuel. It should be noted that methyl esters of colza oil and castor oil, which are cheaper than commercial additives, also allow for improving the lubricity of DME.

Leaks from the fuel system. Factory fuel systems of SI engines fuelled with diesel are not adapted for DME because of great likelihood of leakages. Literature refers to two main causes of such leakages: low viscosity of DME and aggressive action of DME on sealing elements. Even in conditions of atmospheric pressure, DME leakage may be considerable, even if lack of tightness occurs between elements moving between each other, e.g. piston - cylinder in injection pumps, coming to as much as $(40 \div 50) \%$ of the fuel quantity [11]. Greater leakages are observed in case of engines intended for trucks and machinery equipment than in light-duty vehicles [9].

Leakages from the DME fuel systems may be prevented also by increasing its viscosity by applying suitable additives, as discussed earlier and also by exchanging sealing elements prone to corrosion into elements covered with Teflon or made of PTFE [10, 7, 34].

Cavity in the injection system. Due to high vapour pressure of DME cavity may develop in injection systems in engines fuelled with DME. Cavity results in hindered flow of fuel and corrosion of the system's elements. The intensity of cavity increases with the increase of fuel's temperature and occurs more frequently in areas of nondefined, dynamic fuel flow. An effective method of preventing cavity in DME injection systems is to maintain fuel pressure in the system above (1.2-3) $\mathrm{MPa}[11,31]$.

\section{Nomenclature}

DME dimethyl ether

bioDME dimethyl ether of plant origin
SI self-ignition engine

WSD wear scad diameter

\section{Bibliography}

[1] ARCOUMANIS, C., BAE, C., CROOKES, R., KINOSHITA, E. The potential of di-methyl ether (DME) as an alternative fuel for compression-ignition engines: A review. Fuel. 2008, 87, 1014-1030.

[2] BOLLON, F. DME standardization, DME/LPG blends. Mat. Konf. POLBIOF'2007. Kraków 2007.

[3] CIPOLAT, D. Combustion aspects of a compression ignition engine fueled on DME. Proceedings of the seventh international conference on energy for a clean environment; 2003, 156.

[4] CROOKES, R., BOB-MANUEL, K. Di-methyl ether or rapeseed methyl ester: a preferred alternative fuel option for future diesel engine operation. Proceedings of the fifth international colloquium on fuels. 2005, 181-187.

[5] CURRAN, H.J., FISCHER, E.M., GLAUDE, P.A. et al. Detailed chemical kinetic modeling of diesel combustion with oxygenataed fuels. SAE Technical Paper. 2001, 200101-0653.

[6] Dyrektywa Parlamentu Europejskiego i Rady 2009/28/WE z dnia 23 kwietnia 2009 r. w sprawie promowania stosowania energii ze źródeł odnawialnych zmieniająca i w następstwie uchylająca dyrektywy 2001/77/WE oraz 2003/30/WE.

[7] EDGAR, B., DIBBLE, R.W., NAEGELI, D.W. Autoignition of di-methyl ether and di-methoxy methane sprays at high pressures. SAE Technical Paper. 1997, 971677.

[8] FLEISCH, T.H., MEURER, C. DME, the diesel fuel for the 21 st Century? AVL conference engine and environment. 1995.

[9] GOTO, S., OGUMA, M., SUZUKI, S. Research and development of a medium duty DME truck. SAE Technical Paper. 2005, 2005-01-2194.

[10] GÓRSKI, W., JABŁOŃSKA, M. Eter dimetylowy - uniwersalne, ekologiczne paliwo XXI wieku. Nafta-Gaz. 2012, 9, 631-641.

[11] GÓRSKI, W., KULCZYCKI, A. Dimethyl ether. A future fuel for diesel engine? Przemyst Chemiczny. 2009, 88(5), 222-227.

[12] KAORU, F. DME handbook, Japan DME Forum. 2007.

[13] KAPUS, P., OFNER, H. Development of fuel injection equipment and combustion system for DI diesels operated on di-methyl ether. SAE International Journal of Fuels and Lubricants. 1995, 104(4), 54-59.

[14] KAPUS, P.E., CARTELLIERI, W., ULEV potential of a DI/TCI diesel passenger car engine operated on di-methyl ether. SAE Technical Paper. 1995, 952754.

[15] MILLIS, A. Status and future opportunities for conversion of synthesis gas to liquid fuels. Fuel. 1994, 73, 1243-1279.

[16] MINGFA, Y., ZUNQUING, Z., SIDU, X., MAOLING, F. Experimental study on the combustion process of dimethyle ether (DME). SAE Trans J Fuel Lubr. 2003, 112(4), 24222429.

[17] MIYAMOTO, H., OGAWA, H., ARIMA, T., MIUAKIWA, $\mathrm{K}$. Improvement of diesel combustion and emissions with various oxygenated fuel additives. SAE Technical Paper. 1996, 962115.

[18] OGAWA, T., INOUE, N., SHIKADA, T., OHNO, Y. Direct dimethyl ether synthesis. Journal of Natural Gas Chemistry. 2003, 12, 219-227.

[19] PANA, C., NEGURUESCU, N., POPA, M.G. et al. Performance of a DME fueled diesel engine. Proceedings of the fifth international colloquium on fuels. 2005.

[20] PARK, S.H., LEE, C.S. Applicability of dimethyl ether (DME) in a compression ignition engine as an alternative fuel. Energy Conversion and Management. 2014, 86, 848863.

[21] SATO, Y., LEE, S., TAKAYANAGI, T. et al. Research and development of heavy-duty truck fueled with DME - development and performance of a DME engine. 2005.

[22] SEMELSBERGER, T.A., BORUP, R.L., GREENE, H.L. Dimethyl ether (DME) as an alternative fuel. Journal of Power Sources. 2006, 156(2), 497-511.

[23] SIDHU, S., GRAHAM, J., STRIEBICH, R. Semi-volatile and particulate emissions from the combustion of alternative diesel fuel. Chemosphere. 2001, 42, 681-690.

[24] SINIOR, J.E. Consultants, fundamental aspects of dimethyl ether. U.S. Department of Energy. 1998, Washington.

[25] SIVEBAEK, I.M. End-report of annex XX of the IEA/AMF of the IEA. DME as an Automotive Fuel II. Part 2. DTU 2001.

[26] SONG, J., HUANG, Z., QIAO, X., WANG, W. Performance of a controllable premixed combustion engine fueled 
with dimethyl ether. Energy Convers Manage. 2004, 45, 2223-2232.

[27] SORENSON, S.C., GLENSVIG, M., ABATA, D. Di-metyl ether in diesel fuel injection systems. SAE International Journal of Fuels and Lubricants. 1998, 107(4), 438-449.

[28] SORENSONS, S.C., MIKKELSEN, S. Performance and emissions of a 0.2731 direct injection diesel engine fuelled with neat dimethyl ether. SAE Trans J Fuel Lubr. 1995, 104(4), 80-90.

[29] SORENSONS, S.C. Dimethyl ether, in: Alternative fuels for transportation, Ramadhas A. S. (red.). CRC Press, Boca Raton 2010.

[30] TENG, H., MCCANDLESS, J.C., SCHNEYER, J.B. Thermo-chemical characteristics of di-methyl ether - an alterna-

Prof. Stanisław Wojciech Kruczyński, DSc., DEng. Motor Transport Institute.

e-mail: Stanislaw.Kruczynski@its.waw.pl

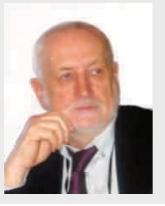

Marcin Ślęzak, DSc., DEng. - Motor Transport Institute.

e-mail: Marcin.Slezak@its.waw.pl

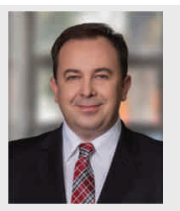

Wojciech Gis, DSc., DEng. - Motor Transport Institute.

e-mail:Wojciech.Gis@its.waw.pl

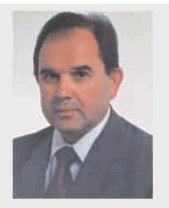

Piotr Orliński, DSc., DEng. - Institute of Vehicles,

Warsaw University of Technology.

e-mail:P.Orlinski@simr.pw.edu.pl tive fuel for compression-ignition engines. SAE Trans J Fuel Lubr. 2001, 110(4), 96-106.

[31] TSUCHIYA, T., SATO, Y. Development of DME engine for heavy-duty truck. SAE Technical Paper. 2006, 52(1).

[32] VERBEEK, R.P., VAN DOOM, A., VAN WALWIJK, M. Global assessment of di-methyl ether as an automotive fuel. second ed., 96.OR.VM.029. 1/RV, TNO Road-Vehicles Research Institute, 1996.

[33] WESTBROOK, C.K. Chemical kinetic modeling of oxygenated diesel fuels in advanced petroleum-based and alternative fuels. DOE Report. 1999.

[34] YU, J., BAE, C. Dimethyl ether (DME) spray characteristics compared to diesel in a common-rail fuel injection system. $J$ Autom Eng Proc IMechE Pt D. 2003, 217, 1135-1144.

Andrzej Kulczycki, DSc., DEng. - Air Force Institute of Technology.

e-mail: klucza@itwl.pl

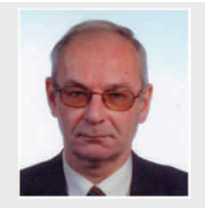

Wojciech Dzięgielewski, DEng. - Air Force Institute of Technology.

e-mail: Wojciech.Dziegelewski@itwl.pl

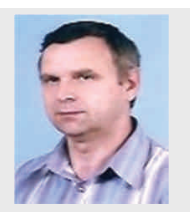

Mateusz Bednarski, MEng - Institute of Vehicles, Warsaw University of Technology.

e-mail: Mateusz.Bednarski@simr.pw.edu.pl
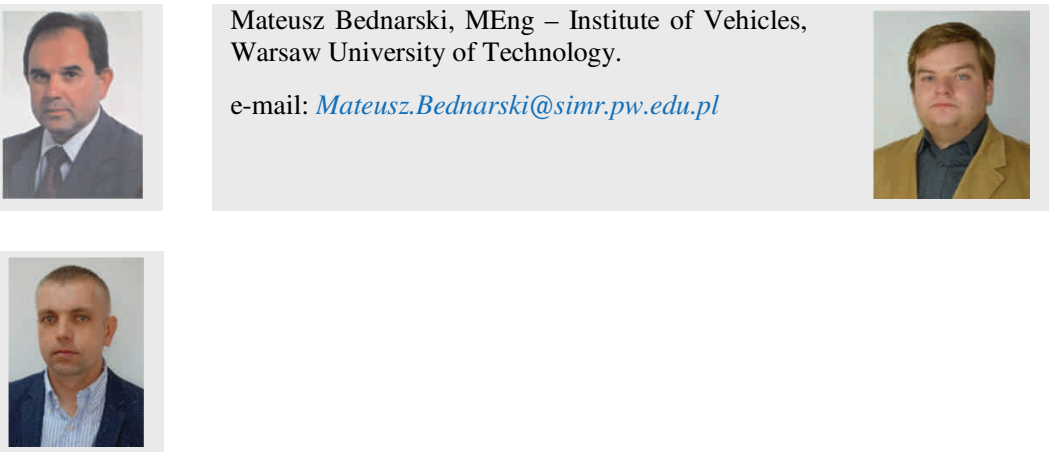